\title{
Confirmation of diagnosis in Romanian children with DFNB1 related hearing loss
}

\author{
Cristina Dragomir ${ }^{1 *}$, Adriana Stan ${ }^{1}$, Dragos Tiberiu Stefanescu ${ }^{1}$, Lorand Savu ${ }^{1}$, \\ Codrut Sarafoleanu ${ }^{2}$, Adrian Toma ${ }^{3}$, Emilia Severin ${ }^{2}$ \\ ${ }^{1}$ Genetic Lab, 43B Ghencea Avenue, Bucharest, Romania \\ ${ }^{2}$ Carol Davila, University of Medicine and Pharmacy, 37 Dionisie Lupu St, Bucharest, Romania \\ ${ }^{3}$ Panait Sirbu Hospital, Calea Giulesti, Bucharest, Romania \\ Email: c_drag@yahoo.com
}

Received 26 May 2013; revised 20 June 2013; accepted 12 July 2013

Copyright (C) 2013 Cristina Dragomir et al. This is an open access article distributed under the Creative Commons Attribution License, which permits unrestricted use, distribution, and reproduction in any medium, provided the original work is properly cited.

\begin{abstract}
DFNB1 locus has been linked to a nonsyndromic "invisible disability" called congenital sensorineural hearing loss and deafness. Mutations of GJB2 and GJB6 genes are associated with deafness at the DFNB1 locus. The diagnosis of DFNB1 is made with molecular genetic testing. DNA-based testing can be used both prenatally and postnatally. Purpose: To get evidence for implementation of newborn hearing screening programs at national level; to use the molecular testing of children at risk for confirmation of diagnosis and early intervention. OAEs and ABR were performed for 4303 newborns. Audiologic evaluation of 38 children suspected of having hearing loss was performed too. Physical examinations and family history were used to get information about congenital deafness. DNA from blood samples was isolated, and two PCR multiplex assays were developed to detect DFNB1 mutations. Only 23 newborns were screened positive. Newborns were referred to audiologic evaluation, genetic counseling and testing for the etiologic diagnosis. Physical examination revealed no other abnormal findings. GJB2 mutations were detected in $\mathbf{3 6 . 0 3 \%}$ of patients, and all of them have 35delG mutation. None of them was found to have GJB6 mutations. Our results suggested that molecular testing was an accurate method of early determining cause of congenital hearing loss and helped us to exclude GJB6 gene from the routine hearing screening protocol.
\end{abstract}

Keywords: DFNB1; Molecular Genetic Testing; GJB2; GJB6

"Corresponding author.

\section{INTRODUCTION}

Hearing loss (HL) affects both children and adults. Agerelated HL is more common than HL in children but "the earlier hearing loss occurs in a child's life, the more serious the effects on the child's development. Similarly, the earlier, the problem is identified and intervention begun, the less serious the ultimate impact" [1]. In this respect, early diagnosis, early management of hearing aids, and an early start on special education programs and using assistive, adaptive and rehabilitative devices could help improvement of a child's hearing.

Genetic HL has diverse etiologies and many genes are known to be involved in hearing process [2-4]. Among them, mutations of GJB2 and GJB6 genes at DFNB1 (OMIM 220290) locus are estimated to play an important role to congenital hearing loss [5-8]. Nowadays, the genetic analysis for hearing loss is used for early diagnosis followed by early intervention programs (invasive interventions, such as, otologic surgery and cochlear implantation or non-invasive interventions, such as rehabilitation), and serves as an explanation for etiology at any age, and for reproductive alternatives in families with affected relatives.

The aims of the study were to get evidence for implementation of newborn hearing screening programs in all neonatal care settings and to use the molecular genetic testing of children at risk (suspected on basis of signs, symptoms or family history) for confirmation of diagnosis and early intervention.

With these aims, we proposed a two-stage study design: stage I-to estimate the carrier frequency of the three mutations namely 35 delG, del(GJB6-D13S1830) and del(GJB6-D13S1854) using amniotic fluid from an unselected group of 350 pregnant women [9] and stage II- to detect mutations of the GJB2 and GJB6 genes in a 
selected group of 61 neonates and children from all over the Romanian zones for which early diagnosis is necessary and available.

\section{MATERIAL AND METHODS}

\subsection{Neonates}

Otoacoustic emissions (OAEs) and auditory brainstem evoked response audiometry (ABR) were performed for 4303 babies born in "Panait Sirbu" Hospital during 2009. Physical examinations and family history were used to get information about hereditary/syndromic hearing loss. All newborns were tested in newborn setting using Echoscreen (Fischer-Zoth).

\subsection{Infants}

Pediatricians from several regions of Romania referred 38 unrelated children (18 males and 20 females) with congenital hearing loss to our ORL/Audiology Clinic. All children were Caucasians and ranging in age from 1 to 7 years. Audiologic evaluation, physical examinations, medical and family history and CT examination of the temporal bone were used to get information about congenital deafness.

\subsection{DNA Extraction}

Standard protocols were used to obtain blood samples from patients and controls for the mutation analysis. DNA from blood samples was isolated and two PCR multiplex assays were developed to detect DFNB1 mutations.

\subsection{ARMs Multiplex PCRs and Multiplex PCR}

DNA was collected from 61 unrelated patients and their parents (child-parents trio). We performed the DNA extraction from peripheral blood cells collected in EDTA vacutainers using the QIAamp DNA Blood Mini Kit (QIAGEN) according with the QIAamp ${ }^{\circledR}$ DNA Mini and Blood Mini Handbook. We proceed from $200 \mu 1$ whole blood sample and we obtained aproximatively $100 \mathrm{ng}$ DNA $/ \mu 1$. We used $400 \mathrm{ng}$ DNA for the detection of 35 delG GJB2 gene mutation and respectively 800 ng DNA for the detection of the two mutations of the GJB6 gene (GJB6-D13S1830 and GJB6-D13S1854 deletions).

We developed two PCR multiplex assays to detect the 35 delG GJB2 mutation using either the normal or the mutant primer along with the common primer proposed by Smith and co-workers [7] and the $\beta$-actin primers. The sequences of forward and revers $\beta$-actin primers were (http://biowww.net/gene/gene-ACTB.html):

5'-TCA CCC ACA CTG TGC CCA TCT ACG A-3';

5'-CAG CGG AAC CGC TCA TTG CCA ATG G-3'.

$\beta$-actin was used as internal control to monitor the
PCR efficiency of two reactions.

Both reactions were performed in a final volume of 25 $\mu \mathrm{l}$ using $400 \mathrm{ng}$ DNA, $1 \mathrm{x}$ PCR buffer, 5 pmol each primer, $1.5 \mathrm{mM} \mathrm{MgCl}_{2}, 200 \mathrm{nM}$ each dNTPs and $1.5 \mathrm{U}$ Power QTaq DNA polymerase (Genomics BioSci\&Tech). PCR conditions were as follow: initial denaturation at 95 ${ }^{\circ} \mathrm{C}$ for 5 minutes followed by 30 cycles of denaturation at $95^{\circ} \mathrm{C}$ for $40 \mathrm{sec}$, annealing at $60^{\circ} \mathrm{C}$ for $30 \mathrm{sec}$, extension at $72^{\circ} \mathrm{C}$ and a final extension step at $72^{\circ} \mathrm{C}$ for $7 \mathrm{~min}$. The expected size of the amplified product was $202 \mathrm{bp}$ for GJB2 and $294 \mathrm{bp}$ for the $\beta$-actin amplicons.

To detect the del(GJB6-D13S1830) and del(GJB6D13S1854) mutations we used the primers and PCR conditions as described by Del Castillo et al., 2005. $800 \mathrm{ng}$ of genomic DNA was amplified for 25 cycles in a $25 \mu \mathrm{l}$ PCR reaction mixture containing $1 x$ PCR buffer, $1.5 \mathrm{mM}$ $\mathrm{MgCl}_{2}, 200 \mu \mathrm{M}$ each dNTP, 10 pmol each primer and 1.5 U of Power QTaq DNA polymerase (Genomics BioSci \& Tech). The method described by Del Castillo et al., 2005, allows the amplification of DNA fragments in a single step. The DNA fragments contain the breakpoint junction of each deletion [for del(GJB6-D13S1854-564 bp and for del(GJB6-D13S1830) - $460 \mathrm{bp}$ ], as well as a fragment with GJB6 exon 1 (333 bp) which is used as an internal control of PCR multiplex efficiency. This method also allows the detection of both heterozygous and homozygous forms of the two deletions. The exon 1 is not amplified when the deletions are present in either homozygous or compound heterozygous forms [8]. Positive controls were kindly offered by Dr. Ignacio Del Castillo from the Unidad de Genetica Molecular, Hospital Ramon y Cajal, Madrid, Spain.

The PCR amplification reactions were run on a GeneAmp PCR System 9700 thermal cycler (Applied Biosystems).

The PCR products were subjected to capillary electrophoresis using the QIAxcel Instrument (Qiagen). The QIAxcel system performs fully automated separation of DNA fragments according to their molecular weight and use capillary electrophoresis to enable high resolution and high sensitivity separation of DNA samples [10].

The DNA-based testing can be used for diagnostic testing, determination of carrier status and prenatal diagnosis of hearing loss.

Written informed consent was obtained from all parents of our minor patients and provided to the Ethics Committee of the Carol Davila University of Medicine and Pharmacy - Bucharest, who approved the conduct of this study in accordance with the Helsinki Declaration.

\section{RESULTS}

\subsection{Neonates}

An unselected population of 4303 neonates was screened 
by $48 \mathrm{~h}$ of age, before discharge, of which 4280 babies had a pass response in both ears at either the initial or follow-up screen.

Only 23 neonates with a positive identification within newborn hearing screening program were referred to audiologic evaluation to confirm if the HL is present. Physical examination revealed no other findings associated with a syndrome. Four newborns with hearing parents were found to have different types of HL: two presented sensorineural hearing loss, one had unilateral hearing loss and one had auditory neuropathy. They were referred to genetic counseling and testing for the etiologic diagnosis.

Incidence of congenital HL among neonates was 0.93 per 1000 live births (four children were clinically diagnosed with $\mathrm{HL}$, out of a total neonate population of 4303).

\subsection{Infants}

Clinical signs could direct the molecular diagnosis to specific genes. So, all of 38 children with congenital HL expressed DFNB1 phenotype associated with sensorineural, prelingual, stable (until now), bilateral, all frequencies affected, and moderately severe hearing impairment. All parents had normal hearing and no consanguine family was identified. Seven children had a history of HL in a close (second or third degree relatives) or distant family member. No sex predilection was no- ticed. No other physical anomalies were detected.

\subsection{ARMS Multiplex PCRs and Multiplex PCR}

GJB2 mutations were detected in $36.03 \%$ of the patients ( $n=22,4$ neonates and 18 children, out of a total of 61 ), all of them having 35 delG mutation. Homozygous status for 35 delG mutation was found in 20 patients and 2 patients were heterozygous for this mutation. Figure 2 shows a representative example of 35 delG GJB2 mutation detection. The PCR reaction with the normal and common pair of primers tests for the presence of normal allele, whereas the PCR reaction with the mutant and common pairs of primers detects the presence of mutant allele.

Two of the 61 homozygous samples and the two homozygous samples were included in the sample set presented in Figure 1.

Beside the screening for the $35 \mathrm{delG}$ mutation we also tested for the del(GJB6-D13S1830) and del(GJB6D13S1854) mutations. These multiplex PCR tests are shown in Figure 2, for the same samples presented in Figure 1.

The band corresponding to exon 1 of GJB6 gene is presented in all samples indicating that the samples were neither homozygous nor compound heterozygous for the two above mentioned mutations. The fact that no bands for either of the two mutations are present indicates that the samples are not heterozygous either.

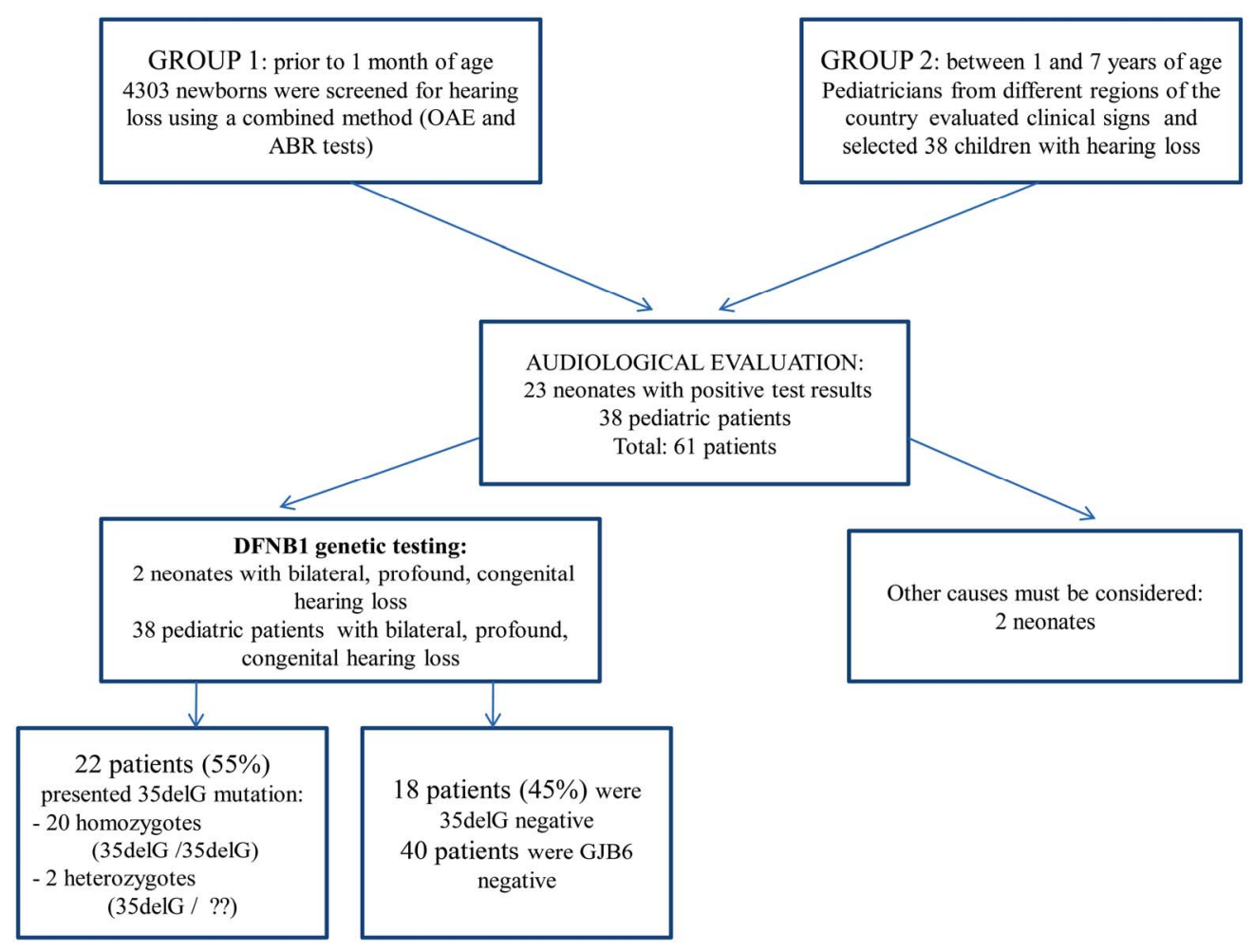

Figure 1. Results of DFNB1 genetic testing. 


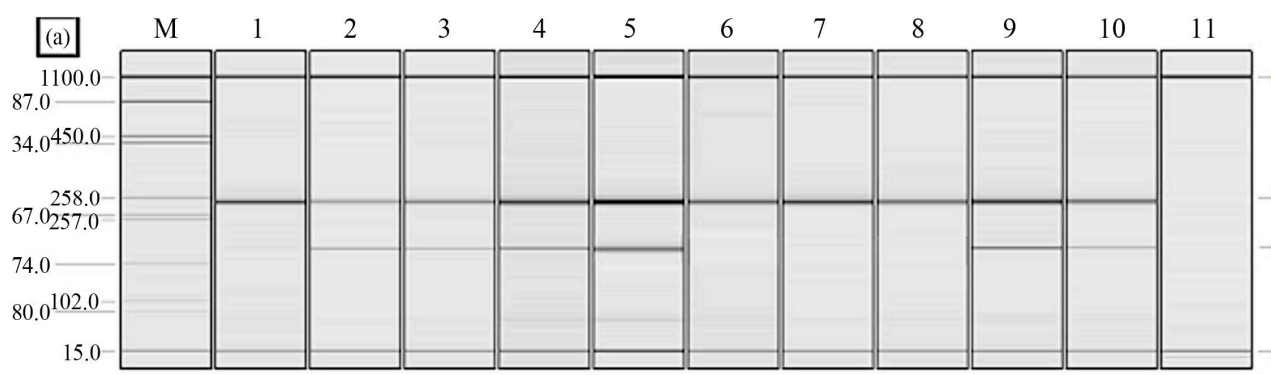

alignment
maker
$\beta$-actin
GJB2
normal allele
alignment
maker
alignment
maker
$\beta$-actin
GJB2
mutant allele
alignment
maker

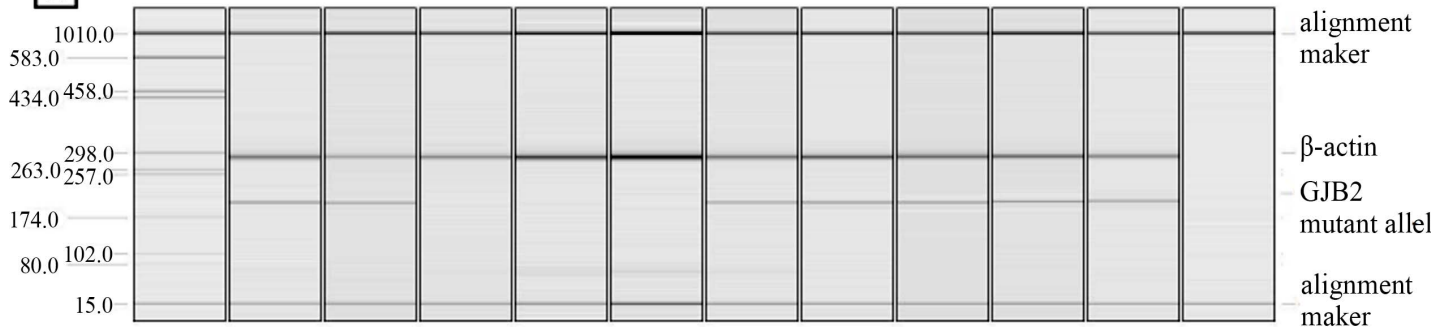

Figure 2. Detection of 35 delG mutation in the GJB2 gene. Panel (a): PCR amplification of genomic DNA using normal and common primers for GJB2 and $\beta$-actin primers. Panel (b): PCR amplification of genomic DNA using mutant and common primers for GJB2 and $\beta$-actin primers. M represents the pUC18/HaeIII marker, Lane 1-homozygous 35delG positive control, Lane 2-heterozygous 35delG positive control, Lane 3-wild-type control, Lane 11-NTC (no template control), Lanes 4, 5-wild-type DNA samples, Lanes 6, 7, 8-35delG homozygous DNA samples, Lanes 9, 10-heterozygous DNA samples.

None of 61 investigated children was found to have del(GJB6-D13S1830) and del(GJB6-D13S1854) mutations.

\section{DISCUSSION}

Until now, many studies investigating populations from Europe, Asia, Australia or North America, have shown that DFNB1 accounts for approximately $50 \%$ of congenital, severe-to-profound, and autosomal recessive nonsyndromic hearing loss [11-21]. GJB2 encodes connexin 26, and GJB6 encodes connexin 30. These are the only two genes known to be associated with deafness at the DFNB1 locus. Approximately $98 \%$ of individuals with DFNB1 have two identifiable GJB2 mutations (i.e., they are homozygotes or compound heterozygotes). More than half of all persons of northern European ancestry with two identifiable GJB2 mutations are homozygous for the c. 35 delG point mutation [7]. Approximately 2\% of individuals with DFNB1 have one identifiable GJB2 mutation and one of two large deletions that include a portion of GJB6. Clinical signs direct the molecular diagnosis to specific genes.

Considering the data from the literature and the facts that Romanians are of Caucasian origin and settled in South Eastern Europe, we decided to start the investigations of DFNB1 related HL. In this respect, our results show the presence and the higher frequency of $35 \mathrm{delG}$ GJB2 mutation among persons of South Eastern Europe and confirm, once more, the European origin of the mutation. In European countries, the prevalence of the 35
delG mutation, in normal-hearing individuals, has been estimated to range from 2 to $4 \%$ [22]. Absence of GJB6 mutations could be explained by the small size sample investigated or the frequency of the mutations is not significant for Romanian population comparable to the data from Italy, Belgium, Turkey and Slovakia [8,23-26].

$\mathrm{HL}$ is the most common birth defect and the most prevalent sensorineural disorder in developed countries [27]. One of every 500 newborns has bilateral permanent sensorineural hearing loss $\geq 40 \mathrm{~dB}$; by adolescence, the prevalence increases to 3.5 per 1000 [28]. The results of the study are of medical interest in audiological practice or family planning but also in the characterization of epidemiological data. The incidence of congenital HL is lower among Romanian neonates than in many European countries but undoubtedly the number of neonates is still significant. In Romania an estimated 200,000 babies are born in Romania each year. This means that around 200 babies with congenital HL should be born each year. Based on our results, newborn hearing screening test detects neonates at-risk and combines with molecular genetic testing, which could early clarify the status of the patient. As early as possible after that, the treatment should start: first, to fit with hearing aids and enrollment in appropriate educational programs and second, to prevent the consequences. So, we suggest that newborn hearing screening test could be offered as a routine test during postpartum hospitalization because it is available and cost-effective. Except few hospitals, the test is offered by request and usually the parents notice the 
handicap of their child too late for intervention. We consider molecular diagnosis as part of evaluation strategy because it confirms the diagnosis in a proband, which could clarify the carrier status of the parents and allows the identification of recurrence risk in future pregnancies. Molecular diagnosis is a complement to clinical examination and not an alternative. The test is available and cost-effective. Non-invasive methods can be used to collect DNA from high-risk neonates and children. Moreover, in Romania rehabilitation and support services are available too.

Also, our results give an overview of the main causes of congenital HL, exclude the GJB6 gene from hearing screening protocols and offer a new strategy for prevention of hearing loss in Romania.

\section{ACKNOWLEDGEMENTS}

We thank all families for their participation in this study.

\section{REFERENCES}

[1] ASHA Web Site (2005) Audiology information series: Effects of hearing loss on development. http://www.asha.org/uploadedFiles/aud/InfoSeriesHearin gLossEffects.pdf

[2] ACMG (2002) Genetics evaluation guidelines for the etiologic diagnosis of congenital hearing loss. Genetic Evaluation of Congenital Hearing Loss Expert Panel: ACMG statement. Genetics in Medicine, 4, 162-171. http://dx.doi.org/10.1097/00125817-200205000-00011

[3] Morton, N.E. (1991) Genetic epidemiology of hearing impairment. Annals of the New York Academy of Sciences, 630, 16-31. http://dx.doi.org/10.1111/j.1749-6632.1991.tb19572.x

[4] Van Camp, G., Willems, P.J. and Smith, R.J. (1997) Nonsyndromic hearing impairment: Unparalleled heterogeneity. The American Journal of Human Genetics, 60, 758-764.

[5] Zelante, L., Gasparini, P., Estivill, X., Melchionda, S., D’Agruma, L., Govea, N., Mila, M., Monica, M.D., Lutfi, J., Shohat, M., Manfield, E., Delgroso, K., Rappaport, E., Surrey, S. and Fortina, P. (1997) Connexin 26 mutations associated with the most common form of non-syndromic neurosensory autosomal recessive deafness (DFNB1) in Mediterraneans. Human Molecular Genetics, 6, 1605-1609. http://dx.doi.org/10.1111/j.1749-6632.1991.tb19572.x

[6] Morell, R.J., Kim, H.J., Hood, L.J., Goforth, L., Friderici, K., Fisher, R., Van Camp, G., Berlin, C.I., Oddoux, C., Ostrer, H., Keats, B., Friedman, T.B. (1998) Mutations in the connexin 26 gene (GJB2) among Ashkenazi Jews with nonsyndromic recessive deafness. The New England Journal of Medicine, 339, 1500-1505. http://dx.doi.org/10.1056/NEJM199811193392103

[7] Scott, D.A., Kraft, M.L., Carmi, R., Ramesh, A., Elbedour, K., Yairi, Y., Srikumari Srisailapathy, C.R., Rosengren, S.S., Markham, A.F., Mueller, R.F., Lench, N.J., Van Camp, G., Smith, R.J.H. and Sheffield, V.C. (1998)
Identification of mutation in the connexin 26 gene that cause autosomal recessive nonsyndromic hearing loss. Human Mutation, 11, 387-394. http://dx.doi.org/10.1002/(SICI)1098-1004(1998)11:5<38 7::AID-HUMU6>3.0.CO;2-8

[8] Del Castillo, I., Villamar, M., Moreno-Pelayo, M.A., Del Castillo, F.J., Alvarez, A., Telleria, D. and Menendez, I., Moreno, F. (2002) A deletion involving the connexin 30 gene in nonsyndromic hearing impairment. The New England Journal of Medicine, 346, 243-249. http://dx.doi.org/10.1056/NEJMoa012052

[9] Dragomir C., Stan A., Stefanescu T.D., Savu L. and Severin E. (2011) Prenatal Screening for the 35delG GJB2, Del (GJB6-D13S1830), and Del (GJB6-D13S1854) Mutations in Romanian Population. Genetic Testing and Molecular Biomarkers, 15, 749-753.

http://dx.doi.org/10.1089/gtmb.2011.0048

[10] Wang, X.W., Rinehart, T.A., Wadl, P.A., Spiers, J.M., Hadziabdic, D., Windham1 M.T. and Robert Trigiano N. (2009) A new electrophoresis technique to separate microsatellite alleles, African Journal of Biotechnology, 8, 2432-2436.

[11] Denoyelle, F., Weil, D., Maw, M.A., Wilcox, S.A., Lench, N.J., Allen-Powell, D.R., Osborn, A.H., Dahl, H.H., Middleton, A., Houseman, M.J., Dode, C., Marlin, S., Boulila-ElGaied, A., Grati, M., Ayadi, H., BenArab, S., Bitoun, P., Lina-Granade, G., Godet, J., Mustapha, M., Loiselet, J., El-Zir, E., Aubois, A., Joannard, A., Petit, C., et al. (1997) Prelingual deafness: High prevalence of a $30 \mathrm{delG}$ mutation in the connexin 26 gene. Human Molecular Genetics, 6, 2173-2177. http://dx.doi.org/10.1093/hmg/6.12.2173

[12] Estivill, X., Fortina, P., Surrey, S., Rabionet, R., Melchionda, S., D’Agruma, L., Mansfield, E., Rappaport, E., Govea, N., Mila, M., Zelante, L. and Gasparini, P. (1998) Connexin-26 mutations in sporadic and inherited sensorineural deafness. Lancet, 351, 394-398. http://dx.doi.org/10.1016/S0140-6736(97)11124-2

[13] Green, G.E., Scott, D.A., McDonald, J.M., Woodworth, G.G., Sheffield, V.C. and Smith, R.J.H. (1999) Carrier rates in the mid-western United States for GJB2 mutations causing inherited deafness. JAMA, 281, 2211-2116. http://dx.doi.org/10.1001/jama.281.23.2211

[14] Kudo, T., Ikeda, K., Kure, S., Matsubara, Y., Oshima, T., Watanabe, K., Kawase, T., Narisawa, K. and Takasaka, T. (2000) Novel mutations in the connexin 26 gene (GJB2) responsible for childhood deafness in the Japanese population. American Journal of Medical Genetics, 90, 141145.

http://dx.doi.org/10.1002/(SICI)1096-8628(20000117)90: 2<141::AID-AJMG10>3.0.CO;2-G

[15] Anichkina, A., Kulenich, T., Zinchenko, S., Shagina, I., Polyakov, A., Ginter, E., Evgrafov, O., Viktorova, T. and Khusnitdonova, E. (2001) On the origin and frequency of the 35 delG allele in GJB2-linked deafness in Europe. European Journal of Human Genetics, 9, 151. http://dx.doi.org/10.1038/sj.ejhg.5200596

[16] Lucotte, G. and Mercier, G. (2001) Meta-analysis of GJB2 mutation 35delG frequencies in Europe. Genet Test, 5, 149-152. 
http://dx.doi.org/10.1089/109065701753145646

[17] Hwa, H.L., Ko, T.M., Hsu, C.J., Huang, C.H., Chiang, Y.L., Oong, J.L., Chen, C.C. and Hsu, C.K. (2003) Mutation spectrum of the connexin 26 (GJB2) gene in Taiwanese patients with prelingual deafness. Genetics in Medicine, 5, 161-165.

http://dx.doi.org/10.1097/01.GIM.0000066796.11916.94

[18] Rothrock, C.R., Murgia, A., Sartorato, E.L., Leonardi, E., Wei, S., Lebeis, S.L., Yu, L.E., Elfenbein, J.L., Fisher, R.A. and Friderici, K.H. (2003) Connexin 26 35delG does not represent a mutational hotspot. Human Genetics, 113, 18-23.

[19] Najmabadi, H., Nishimura, C., Kahrizi, K., Riazalhosseini, Y., Malekpour, M., Daneshi, A., Farhadi, M., Mohseni, M., Mahdieh, N., Ebrahimi, A., Bazazzadegan, N., Naghavi, A., Avenarius, M., Arzhangi, S. and Smith, R.J. (2005) GJB2 mutations: Passage through Iran. American Journal of Medical Genetics Part A, 133, 132-137. http://dx.doi.org/10.1002/ajmg.a.30576

[20] Lazar, C., Popp, R., Trifa, A., Mocanu, C., Al-Khzouz, C., Tomescu, E., Figan, I. and Grigorescu-Sido, P. (2010) Prevalence of the c.35delG and p.W24X mutations in the GJB2 gene in patients with nonsyndromic hearing loss from North-West Romania. International Journal of Pediatric Otorhinolaryngology, 74, 351-355.

[21] Mahdieh N., Rabbani B., Wiley S., Akbari M.T. and Zeinali S. (2010) Genetic causes of nonsyndromic hearing loss in Iran in comparison with other populations. Journal of Human Genetics, 55, 639-648.

[22] Gasparini, P., Rabionet, R., Barbujani, G., Melchionda, S., Petersen, M. and Brondum-Nielsen, K. (2000) High carrier frequency of the $35 \mathrm{delG}$ deafness mutation in European populations. Genetic Analysis Consortium of GJB2 35delG. European Journal of Human Genetics, 8, 19-23. http://dx.doi.org/10.1038/sj.ejhg.5200406

[23] Del Castillo, I., Moreno-Pelayo, M.A., Del Castillo, F.J., Brownstein, Z., Marlin, S., Adina, Q., Cockburn, D.J., Pandya, A., Siemering, K.R., Chamberlin, G.P., Balana, E., Wuyts, W., Maciel-Guerra, A.T., Alvarez, A., Villamar, M., Shohat, M., Abelivich, D., Dahl, H.H.M., Esti- vill, X., Gasparini, P., Hutchin, T., Nance, W.E., Sartorato, E.L., Smith, R.J.H., Van Camp, G., Avraham, K.B., Petit, C. and Moreno, F. (2003) Prevalence and evolutionary origins of the del (GJB6-D13S1830) mutations in the DFNB1 locus in hearing impaired subjects: A multicenter study. The American Journal of Human Genetics, 73, 1452-1458. http://dx.doi.org/10.1086/380205

[24] Del Castillo, F.J., Rodrigues-Ballesteros, M., Alvarez, A., Hutchin, T., Leonardi, E., De Oliveira, C.A., Azaiez, H., Brownstein, Z., Avenarius, M.R., Marlin, S., Pandya, A., Shahin, H., Siemering, K.R., Weil, D., Wuyts, W., Aguirre, L.A., Martin, Y., Moreno-Pelayo, M.A., Villamar, M., Avraham, K.B., Dahl, H.H.M., Kanaan, M., Nance, W.E., Petit, C., Smith, R.J.H., Van Camp, G., Sartorato, E.L., Murgia, A., Moreno, F. and Del Castillo, I. (2005) A novel deletion involving the connexin-30 gene, del (GJB6-d13s1854), found in trans with mutations in the GJB2 gene (connexin-26) in subjects with DFNB1 nonsyndromic hearing impairment. Journal of Medical Genetics, 42, 588-594.

http://dx.doi.org/10.1136/jmg.2004.028324

[25] Sirmaci, A., Akcayoz-Duman, D. and Tekin, M. (2006). The c.IVS1+1G $>$ A mutation in the GJB2 gene is prevalent and large deletions involving the GJB6 gene are not present in Turkish population. Journal of Genetics, 85, 213-216.

[26] Minarik, G., Tretiarova D., Szemes T. and Kadasi L. (2012) Prevalence of DFNB1 mutations in Slovak population with non-syndromic hearing loss. International Journal of Pediatric Otorhinolaryngology, 76, 400-403. http://dx.doi.org/10.1016/j.ijporl.2011.12.020

[27] Hilgert, N., Smith, R.J. and Van Camp, G. (2009) Forty-six genes causing nonsyndromic hearing impairment: Which ones should be analyzed in DNA diagnostics. Mutation Research, 681, 189-96. http://dx.doi.org/10.1016/j.mrrev.2008.08.002

[28] Morton, C.C. and Nance, W.E. (2006) Newborn hearing screening-A silent revolution. The New England Journal of Medicine, 354, 2151-2164. http://dx.doi.org/10.1056/NEJMra050700 